\title{
Prevalence of Antibodies to Hepatitis B Core Antigen in Blood Donors In the Middle West Region of Brazil
}

\author{
José Ivan Aguiar $/{ }^{+}$, Eliana Aguiar, Anamaria Paniago, Rivaldo Cunha, \\ Luciney Galvão*, Roberto Daher**
}

\author{
Universidade Federal do Mato Grosso do Sul, Av. Fellinto Muller s/nº, 79070-900 Campo Grande, MS, Brasil \\ *Centro de Hematologia e Hemoterapia de Mato Grosso do Sul, Campo Grande, MS, Brasil \\ **Instituto de Medicina Tropical e Saúde Pública, Universidade Federal de Goiás, Goiânia, GO, Brasil
}

The prevalence of antibodies to hepatitis B core antigen in 552 prime blood donors was of $9.4 \%$. The majority $(71.2 \%)$ has antibodies to hepatitis B surface antigen. The hepatitis $B$ surface antigen was present in $0.7 \%$, all of them antibodies to hepatitis B core antigen positive.

Key words: antibodies to hepatitis B antigen - hepatitis B - hepatitis C

The introduction of screening test for hepatitis B surface antigen (HBsAg) in blood donors contributed to a marked reduction in the incidence of post transfusion hepatitis B (PTH). The adopted screening test for antibody against hepatitis B virus core (anti-HBc) as an alternative marker for non-A, non-B hepatitis (NANBH), also contributed to prevent PTH in the past. However, at the present time its importance has decreased, mainly due the availability of sensitive methods for detection of hepatitis $\mathrm{C}$ infection. Even so, the presence of anti$\mathrm{HBc}$ antibodies can be considered as an indicator of the risk for other parenterally transmitted viruses such as hepatitis $\mathrm{C}$ virus (HCV) and human immunodeficiency virus (HIV). It can also help to prevent hepatitis $B$ virus (HBV) infection transmitted by some HBsAg negative donors (Mosley et al. 1995).

In Brazil, especially in high prevalence areas for $\mathrm{HBV}$, blood banks have recorded high levels of anti-HBc positivity (up to $57 \%$ ) leading to the exclusion of a significant number of donors (Hemopa 1994).

This study aimed to determine the prevalence of anti-HBc antibodies in blood donors from the middle west region of Brazil and its association with alanine aminotransferase (ALT) levels, other

\footnotetext{
${ }^{+}$Corresponding author. Fax: +55-21-67.751.0531. E-mail: jivan@ nin.ufms.br Received 16 August 1999 Accepted 27 September 2000
}

HBV markers and HCV antibodies. In addition, we evaluated the effectiveness of the clinical and epidemiological screening in pre-donation, using the anti-HBc as a surrogate marker.

A total of 552 prime blood donors were studied. This sample size was estimated according to the size of the population (634,416 inhabitants). Before the study, a pilot survey found a $6 \%$ positivity rate for anti-HBc antibodies. The sample population represented approximately $20 \%$ of the demand of prime donors and constituted a sectional study among candidates for first time donation. It included an adult population with age among 19 and 54 years and was carried out at the Hematology Center (Hemosul), in the city of Campo Grande, State of Mato Grosso do Sul. The candidates were submitted to a standard questionnaire for evaluating the presence of risk factors associated with post-transfusional diseases.

Serological tests were performed by enzyme immunoassay (Hepanostika Organon) for the detection of HBV markers (HBsAg, anti-HBc, antiHBs); antibodies to HCV (UBI HCV Eia 4.0 Organon). ALT levels were determined using the colorimetric Reitman and Frankel method and values equal to or above $64 \mathrm{U} / \mathrm{ml}$ were considered abnormal. The positive samples for anti-HBc were tested for anti-HBs. Anti-HBc was investigated in blood donors excluded in pre-donation screening. Statistical analysis was performed using the Epiinfo 6.0 program (Dean et al. 1994).

Among the 552 subjects, $4(0.7 \%)$ were positive for HBsAg, 52 (9.4\%) for anti-HBc, $14(2.5 \%)$ for anti-HCV. Abnormal levels of ALT were found in 11 individuals (2\%). The HBsAg prevalence was similar to that recorded in the city of Florianópolis, 
State of Santa Catarina, by Vasconcelos et al. (1994). According to Zuckerman (1985), this HBsAg prevalence is consistent with a low prevalence pattern of $\mathrm{HBV}$ infection $(0.2-0.5 \% \mathrm{HBs} \mathrm{Ag})$.

The anti-HBc prevalence was in agreement with the rates observed in São Paulo, State of São Paulo, by Wendel et al. (1991) and Gonçales Júnior et al. (1993).

Among the 52 anti-HBc positive individuals, 4 presented HBsAg (7.7\%) and 37 (71.2\%) were positive for anti-HBs. The elevated concomitant positivity for anti-HBc and anti-HBs was previously reported by Burrel (1980), Gonçales Júnior et al. (1993), Barbara (1994) and Mosley et al. (1995). These findings indicates a previous infection and immunity to $\mathrm{HBV}$, although the degree of protection depends on the anti-HBs levels. On the other hand, the use of the anti-HBc as a marker for previous HBV infection is considered of great epidemiological value, given that it is rarely negative when the infection is or was present. It can be the only marker which persists between the disappearance of HBsAg and the appearance of anti-HBs and it represents the residual long lasting antibody present after the disappearance of anti-HBs (Mcmahon et al. 1981, Hadler et al. 1984).

Among the subjects anti-HBc positive, 21\% (11/52) presented it as the only serological HBV marker present. In low prevalence areas for HBV, the occurrence of isolated anti-HBc practically exempts the possibility of PTH (Scully et al. 1994, Mosley et al. 1995). In contrast, in high endemicity areas, anti-HBc as the sole HBV marker has been associated with the presence of HBV-DNA detected using the polymerase chain reaction (PCR) (Luo et al. 1991, Wang et al. 1991, Nandi \& Banerjee 1992, Chung et al. 1993, SánchezQuijano et al. 1993). Among individuals with isolated anti-HBc, Jilg et al. (1995) found a level of $32.9 \%$ of HBV-DNA positivity by PCR, most of them presenting low virus concentration. In an analysis of individuals with this same serological profile, Jamelka et al. (1994) found 39\% of positivity for HBV-DNA and showed that the presence of HBV-DNA was associated with HBsAg/antiHBs immune complexes in $31 \%$. However, the significance of HBV-DNA by PCR for analysis of HBV infectivity remains uncertain. Gomes et al. (1996) demonstrated that samples presenting isolated anti-HBc as well as anti-HBc/anti-HBs contain HBV-DNA at a very low concentration, close to the limit of detection. Moreover, the occurrence of false anti-HBc positivity was reported by Douglas et al. (1993) and Hughes et al. (1995).

The overall prevalence of $2.5 \%$ for anti-HCV in this study was similar to those noted by Vanderborght et al. (1993) in the city of Rio de
Janeiro. We found a low rate (1.9\%) of anti-HBc among blood donors anti-HCV positive and Vasconcelos et al. (1994) found (2.7\%).The importance of anti-HBc as an alternative $\mathrm{HCV}$ marker has been questioned following the introduction of sensitive HCV tests for the screening of donors (Barbara 1994, Dodd 1995). However, it has been reported that anti-HBc screening can eventually prevent some HCV cases in high HBV prevalence areas (Mosley et al. 1995). Jilg et al. (1995) studying isolated anti-HBc individuals, found antiHCV antibodies in $40.5 \%$, of which $2 / 3$ were $\mathrm{HCV}$ RNA positive.

Among 552 blood donors studied 11 (2\%) presented abnormal ALT levels. The association anti$\mathrm{HBc}$ and abnormal ALT was of 3.8\% (2/52). Wendel et al. (1991) found ALT levels of $85 \mathrm{UI} /$ 1 or higher in $1.4 \%$ of blood donors. Vasconcelos et al. (1994) reported a significant correlation among anti-HBc positivity and elevated ALT levels. Vanderborght et al. (1993) also reported an increasing reactivity for anti-HCV associated with ALT elevation. Concerning the NIH (1995) evaluation, the maintenance of ALT screening did not improve the transfusion safety even during the infection, prior to the appearance of anti-HCV. The consensus also admitted that the anti-HBc screening does not identify additional donors capable of transmitting $\mathrm{HCV}$ and it can reduce the risk of transmission of HBV from chronically infected donors, with undetectable levels of HBsAg. In some cases, it can prevent the HIV transmission during the window period.

A total of 73 blood donors (13\%) were excluded by pre-donation screening. Serological testing of these revealed the presence of five anti-HBc positive $(6.8 \%)$ denoting a low rate among these blood donors.

In conclusion, our results showed a low prevalence of HBsAg in blood donors from the city of Campo Grande. The anti-HBc prevalence was 9.4\% which for the majority of donors indicated past infection due to the presence of anti-HBs. A frequency of association anti-HBc/anti-HCV was $1.9 \%$ and with abnormal ALT levels of 3.8\%. However, 11 donors $(21 \%)$ who presented isolated anti$\mathrm{HBc}$ could eventually represent a potential risk for HBV transmission. In light of the different prevalences found in several regions from our country, studies must be encouraged to better understand the real significance of anti-HBc positivity in donors and if necessary redefine prophylactic measures of control.

\section{REFERENCES}

Barbara JAJ 1994. Hepatitis B: old virus, new problems? Vox Sang 67: 239-242. 
Burrel CJ 1980. Serological markers of hepatitis B. Clin Gastroenterol 9: 47-63.

Chung HT, Lee JS, Lok AS 1993. Prevention posttransfusion hepatitis $\mathrm{B}$ and $\mathrm{C}$ by screening for antibody to hepatitis $\mathrm{C}$ virus and antibody to $\mathrm{HBcAg}$. Hepatology 18: 1045-1049.

Dodd RY 1995. Transfusion-transmitted hepatitis virus infection. Hematol/Oncol Clin North Am 9: 137-153.

Dean AG, Dean JA, Coulombier D, Brendel KA, Smith DC, Burton AH, Dicker RC, Sullivan K, Fagan RF, Arner TG 1994. Epi Info, version 6. A word processing database, and statistics program for epidemiology on microcomputers, Center of Diseases Control and Prevention, Atlanta, GA.

Douglas DD, Taswell HF, Rekela J, Rabe D 1993. Absence of hepatitis B virus DNA detected by polymerase chain reaction in blood donors who are hepatitis B surface antigen negative and antibody to hepatitis B core antigen positive from a United States population with low prevalence of hepatitis B serological markers. Transfusion 33: 212-216.

Gomes AS, Yoshida CFT, Niel C 1996. Detection of hepatitis B virus DNA in hepatitis B surface antigen-negative serum polymerase chain reaction: evaluation of different primer pairs and conditions. Acta Virol 40: 133-138.

Gonçales Júnior FL, Boccato RSB, Pedro RJ, da Silva LJ, Papaiordanou PMO, Souza CA, Gonçales NSL, Pellegrino Júnior J 1993. Prevalências do HBsAg, do anti-HBc e do anti-HCV na população de candidatos a doadores de sangue do HemocentroCampinas. Rev Inst Med Trop São Paulo 35: 45-51.

Hadler SC, Murphy BL, Schable CA, Heyward WL, Francis DP, Kane MA 1984. Epidemiological analysis of the significance of low positive test results on antibody to hepatitis B and core antigens. J Clin Microbiol 19: 521-525.

Hemopa-Hemocentro do Estado do Pará 1994. Informativo Hemopa $n^{\circ} 6$.

Hughes W, Barr A, Dow BC, Follett EA, Barbara JAJ 1995. A multicenter assessment of the specificity of ten anti-HBc screening tests. Transfus Med 5: 225230.

Jamelka HIJ, Wicki NA, Grob PJ 1994. Detection of $\mathrm{HBs}$ antigen in "anti-HBc alone" positive sera. $J$ Hepatol 21: 269-272.

Jilg W, Sieger E, Zachoval R, Schätzl H 1995. Individuals with antibodies against hepatitis $B$ core antigen as the only serological marker for hepatitis B infection: high percentage of carriers of hepatitis B and C virus. J Hepatol 23: 14-20.
Luo KX, Zhou R, Chao H, Liang ZS, Jiang S 1991. Hepatitis B virus DNA in sera of virus carriers positive exclusively for antibodies to the hepatitis B core antigen. J Med Virol 35: 55-59.

McMahon DJ, Bender TR, Berquist KR, Schreeder MT, Harpster AP 1981. Delayed development of antibody to hepatitis B surface antigen for symptomatic infection with hepatitis B virus. J Clin Microbiol 14: 130-134.

Mosley JW, Stevens CE, Aach RD, Hollinger FB, Mimms LT, Solomon LR, Barbosa LH, Nemo GJ 1995. Donor screening for antibody to hepatitis B core antigen and hepatitis B virus infection in transfusion recipients. Transfusion 35: 5-12.

Nandi J, Benerjee K 1992. Detection of hepatitis B virus DNA in donor blood by the polymerase chain reaction. Nat Med J India 5: 5-7.

NIH-National Institute of Health 1995. Infectious disease testing for blood transfusion. Consens Statement 13: 1-29.

Sánchez-Quijano A, Jauregui JI, Leal M, Pineda JA, Castilla A, Abad MA, Civeira MP, Garcia de Pesqueira F, Prieto J, Lissen E 1993. Hepatitis B virus occult infection in subjects with persistent isolated anti-HBc reactivity. J Hepatol 17: 288-293.

Scully LJ, Sung H, Pennie R, Gill P 1994. Detection of hepatitis B virus DNA in the serum of Canadian hepatitis B surface antigen negative, anti-HBc positive individual, using the polymerase chain reaction. J Med Virol 44: 293-297.

Vanderborght BOM, Reis AMM, Rouzerè C, Yoshida CFT, Franco LGP, Van Heuverswijn H, Moreira Pereira J 1993. Prevalence of anti-Hepatitis C virus in the blood donor population of Rio de Janeiro, Brazil. Vox Sang 65: 122-125.

Vasconcelos HCFF, Yoshida CFT, Vanderborght BOM, Schatzmayr HG 1994. Hepatitis B and C prevalences among blood donors in the south region of Brazil. Mem Inst Oswaldo Cruz 89: 503-507.

Wang JT, Wang TH, Sheu JC, Shih LN, Lin JT, Chen DS 1991. Detection of hepatitis B virus DNA by polymerase chain reaction in plasma of volunteer blood donors negative for hepatitis B surface antigen. J Infect Dis 163: 397-399.

Wendel S, Luzzi JR, Russo C, Fontão RCL, Ghaname J 1991. Pesquisa de anti-HBc em doadores de sangue em São Paulo: deverá esse teste ser adotado pelo Brasil? Rev Paul Med 109: 77-83.

Zuckerman AJ 1985. Controversies in immunization against Hepatitis B. Hepatology 5: 1227-1230. 